\title{
Functional outcomes following surgical treatment of chronically unreduced simple elbow dislocations: a retrospective review
}

\author{
Yende $\mathrm{T}^{1}$, Senoge $\mathrm{ME}^{2}$, Ferreira $\mathrm{N}^{3}$ \\ 1 Biomed Technology, MBChB, HDipOrth(SA), FCOrth(SA); Department of Orthopaedic Surgery, Grey's Hospital, University of KwaZulu-Natal, \\ Pietermaritzburg \\ $2 \mathrm{MBChB}, \mathrm{FCOrth}(\mathrm{SA})$; Department of Orthopaedic Surgery, Grey's Hospital, University of KwaZulu-Natal, Pietermaritzburg \\ 3 BSc, MBChB, FCOrth(SA), MMed(Orth)(SA), PhD; Professor and Head Clinical Unit: Tumour, Sepsis and Reconstruction; Division of Orthopaedics, \\ Stellenbosch University, Cape Town
}

Corresponding author: Dr Thabiso Yende, Department of Orthopaedic Surgery, Grey's Hospital, Nelson R Mandela School of Medicine, University of KwaZulu-Natal, Pietermaritzburg, 3201, South Africa; tel: +27720827766; email: thabisoy@yahoo.com

\begin{abstract}
Background: Chronic elbow dislocations are rare injuries that present late for orthopaedic management. The delay in presentation is frequently due to patients not seeking treatment after the initial injury, poor access to health care, inadequate initial treatment of acute dislocation or initial missed diagnosis. Chronic simple elbow dislocations refer to dislocations that remain unreduced for more than two weeks and are not associated with fractures. This study aims to evaluate the outcome of surgically treated chronic elbow dislocations. Methods: A retrospective review of all patients who were treated for chronic simple elbow dislocations between September 2009 and August 2014 was undertaken. Further information regarding return to function was obtained from the records or telephonic consultation with the patients. Nine patients were included for final analysis.

Results: Nine patients were eligible for the study. Three patients were employed, three were scholars and three were unemployed. All patients were able to return to premorbid function with minor limitations due to occasional pain. According to the Mayo Elbow Performance Index (MEPI) score, two patients had excellent outcomes, three good and three fair. One could not be scored as there was no recorded scoring on the file and telephonic contact was unsuccessful. The range of motion varied from $20^{\circ}$ of extension to $140^{\circ}$ of flexion. One patient developed a stiff elbow but was able to adapt to activities of daily living.

Conclusion: Surgical treatment of chronically unreduced simple elbow dislocations offers satisfactory outcome with minimal complications and should be considered for all patients presenting with this condition.
\end{abstract}

Level of evidence: Level 4

Key words: chronic elbow dislocation, functional outcomes, MEPI

Citation: Yende T, Senoge ME and Ferreira N. Functional outcomes following surgical treatment of chronically unreduced simple elbow dislocations: a retrospective review. SA Orthop J 2018;17(4):33-38. http://dx.doi.org/10.17159/2309-8309/2018/v17n4a4

Editor: Dr C Breckon, University of the Witwatersrand

Received: January 2018

Accepted: July 2018

Published: November 2018

Copyright: ( $) 2018$ Yende T. This is an open-access article distributed under the terms of the Creative Commons Attribution Licence, which permits unrestricted use, distribution and reproduction in any medium, provided the original author and source are credited.

Funding: The authors received no funding for this study.

Conflict of interest: The authors declare they have no conflicts of interest with respect to the publishing of this study. 


\section{Background}

Acute elbow dislocations are frequently encountered in emergency units. These injuries are as a result of high energy trauma which may be due to falls, sports injuries, assault or motor vehicle accidents, and account for approximately $20 \%$ of all articular dislocations. Despite the frequency of acute elbow dislocations, chronic elbow dislocations are rare. ${ }^{1,2}$ Patients with chronic elbow dislocations are frequently the result of their not seeking treatment after the initial injury, poor access to health care, inadequate initial treatment of acute dislocation or initial missed diagnosis. ${ }^{1-3}$

Neglected (chronic) elbow dislocations are defined as dislocations left unreduced for more than two weeks. ${ }^{1-4}$ These injuries are uncommon in developed countries, ${ }^{5}$ but more frequently encountered in developing countries., ${ }^{3,6}$ Dislocations without concomitant fractures are termed 'simple dislocations' while dislocations that are associated with fractures of the coronoid process, radial head or neck, distal humerus or olecranon are termed 'complex dislocations'.?

Patients with chronic elbow dislocations present with disability as a result of a fixed position or decreased range of motion (ROM). Many of these individuals are of an economically active age group and in many instances are the only breadwinners in the family. Available literature has reported favourable to excellent results for surgical management of these injuries using outcome measures which include DASH (disabilities of the arm, shoulder and hand), MEPI (Mayo Elbow Performance Index) and Krishnamoorthy scores. These scoring systems provide an idea of the patient's function, pain and ROM but do not provide information regarding patient's activities of daily living (ADLs), satisfaction with surgery, return to premorbid function, or if they would recommend surgery to other patients with similar injuries.

This study aims to report patient satisfaction following surgical treatment of chronic simple elbow dislocations, evaluate return to premorbid function and gather information that may help in preoperative counselling of patients in terms of the expected outcomes of surgery and rehabilitation.

\section{Materials and methods}

A retrospective review of all patients with chronic simple elbow dislocations that were surgically treated between September 2009 and August 2014 was performed. Ethical approval was obtained from the institutional ethics committee before commencement of the study. Eligible patients were identified from a prospectively collected database. Patients were contacted telephonically to ascertain functional recovery and satisfaction with surgery. Patients were excluded if dislocations were acute, associated with fractures, lost to follow-up, refused surgery or refused to participate.

Simple elbow dislocations were defined as dislocations with no associated fractures. Chronic dislocations were defined as dislocations that remained unreduced for more than two weeks following the injury.

Surgery was performed with patients in either a lateral or prone position. A tourniquet was used in all cases. A long posterior incision was followed by identification and anterior transposition of the ulnar nerve in all patients. The medial and lateral paratricipital approach provided access to the distal humerus and elbow joint. A muscle slide procedure was performed for the common flexor and extensor origins. All fibrous tissue in the olecranon fossa was debrided and followed by circumferential capsular release (Figures 1 and 2). The elbow was then reduced. The elbow was flexed maximally to stretch the triceps. We planned to proceed with triceps lengthening if intra-operative elbow flexion was less than $130^{\circ}$. No patient required triceps lengthening. One patient had

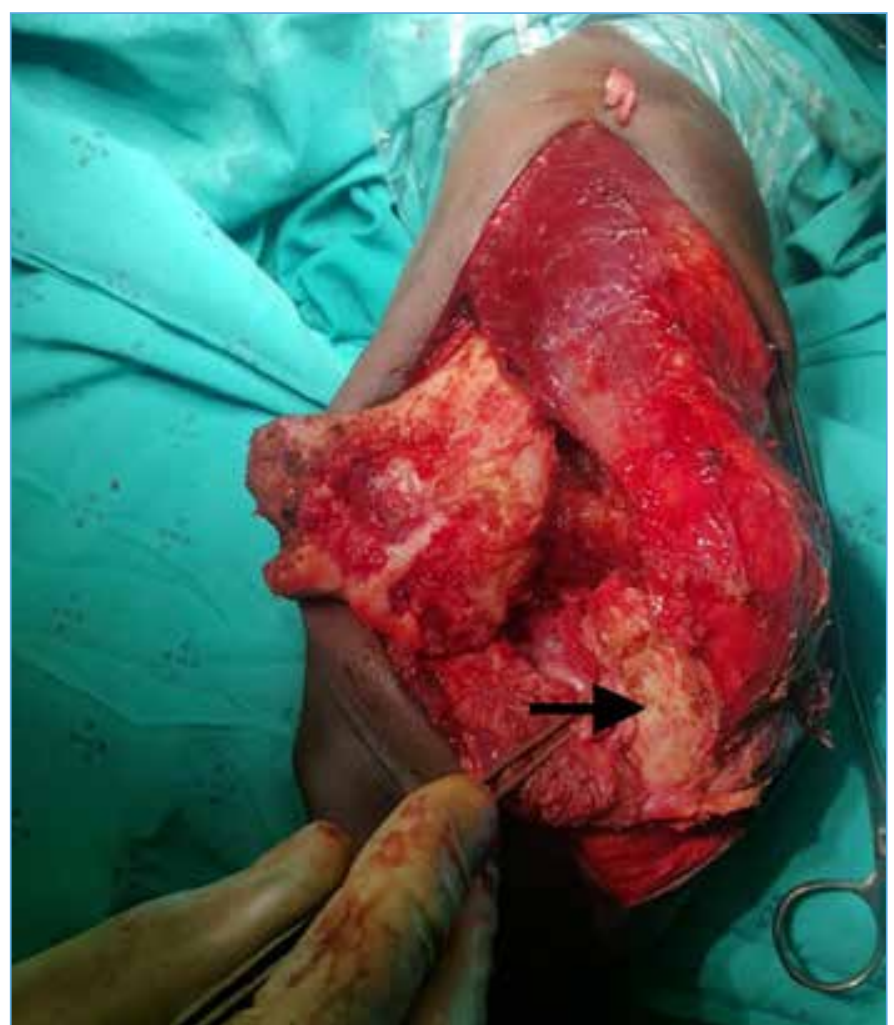

Figure 1. Circumfential release done; figure shows fibrous tissue in the olecranon fossa

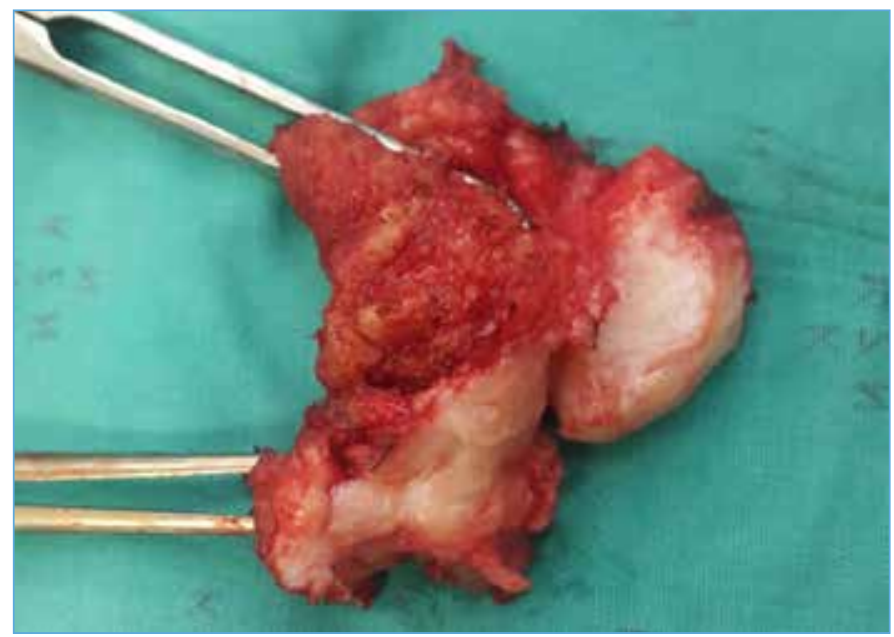

Figure 2. Fibrous tissue excised from the olecranon fossa

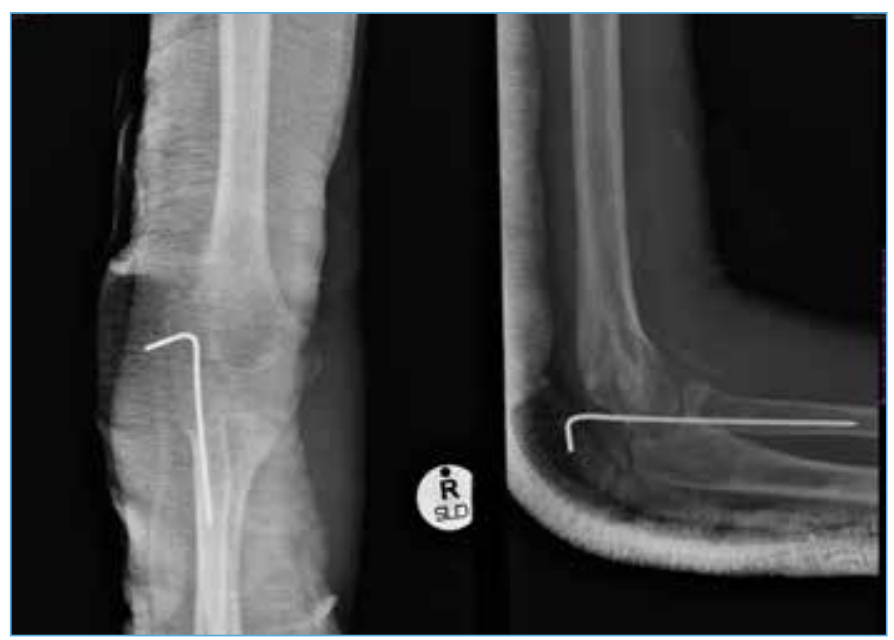

Figure 3. Post-operative radiographs of the patient who had a divergent dislocation with humero-radial wire 
medial and lateral collateral ligament repair with suture anchors as reduction was unstable intra-operatively. A $2 \mathrm{~mm}$ K-wire was then inserted through the olecranon to the distal humerus (Figure 3). One patient with a divergent dislocation had a radiocapitellar wire insertion to prevent lateral subluxation of the radial head. Haemostasis was ensured following release of the tourniquet. Wounds were closed in layers over a $3 \mathrm{~mm}$ drain. An above-elbow plaster of Paris backslab was applied for a period of two to three weeks after which rehabilitation under the supervision of the occupational therapist was commenced. Patients were considered for indomethacin prophylaxis against heterotopic ossification as per the operating surgeon's discretion. One patient was initially treated with a hinged external fixator for joint distraction followed by open reduction one week later.

Rehabilitation was goal-directed and commenced between two and eight weeks post-operatively. The focus was on scar and pain management and initiation of active assisted ROM, taking care not to overstretch healing tissues. Progressive serial dynamic splinting was used for patients who were not showing improvement in ROM without splintage. Scars were massaged with aqueous cream at least twice per day and patients were taught how to do this at home. Patients were also encouraged to do active assisted exercises at home.

At two months following the surgery, rehabilitation focused on improvement of ROM, muscle strengthening and functional use. Both active assisted and active ROM was encouraged and patients were taught how to do this at home. Aggressive passive mobilisations were avoided in order to minimise the risk of developing heterotopic ossification. Cold packs were used for flare up of inflammation. Serial splinting was continued for patients who did not show improvement of ROM.

\section{Results}

Twenty patients with chronic elbow dislocations were treated during the study period. Eleven patients were excluded from the study. These included five patients whose files could not be found, four who had associated fractures, one who refused surgery and one who was lost to follow-up immediately following surgery.

Nine patients with a mean follow-up of 8.1 months ranging from one to 24 months were included for analysis. The study population consisted of three women and six men. The median age was 27 years, ranging from six to 47 years. The median time duration from injury to surgical treatment was 5 months, ranging from 1 to 7 months (Table I). Eight patients (88.9\%) presented with a history of falling while the remaining patient had been assaulted. One was an active smoker and one patient was HIV positive and on antiretroviral treatment.

Seven patients $(77.8 \%)$ sought medical treatment immediately post injury while two did not seek any treatment because they thought the injury was not significant. Of the seven patients who sought immediate treatment, two were immobilised in a plaster of Paris backslab without reduction, three were reduced and placed in a collar and cuff, one had no reduction nor splinting and one patient was reduced, immobilised in a plaster of Paris backslab and reduction confirmed on radiographs. This patient was then lost to follow-up and presented seven months after the initial injury with the history that she had fallen again three weeks earlier.

Four patients (44.4\%) had posterior dislocations, four (44.4\%) had posterior-lateral dislocations and one patient $(11.1 \%)$ had a divergent-type elbow dislocation. The patient with the divergent dislocation was initially treated with external fixator for joint distraction. This was followed by open reduction with posterior approach and K-wire one week later. All other patients were treated with open reduction and $\mathrm{K}$-wire as a single stage procedure.
Concentric reduction of the ulno-humeral and radio-capitellar joints was obtained in all patients following surgery. ROM varied from patient to patient with extension to flexion ranging between $20^{\circ}$ to $140^{\circ}$ (Table I). The ROM and MEPI scores obtained were independent of duration from time of dislocation to surgery. Eight patients had full forearm supination and pronation while one developed a stiff elbow with forearm in $30^{\circ}$ pronation.

Complications included heterotopic ossification in one patient, superficial wound sepsis which resolved with oral antibiotics in one patient and early elbow osteo-arthritis in one patient. No neurological injury as a result of the initial injury or surgery was encountered.

During telephonic follow-up, only five patients could be reached. All five of the patients reported being satisfied with the outcome of surgery and would recommend surgery to other patients with similar injuries. The sixth patient was satisfied with surgery according to last follow-up notes on the patient's records but there is no record on whether he would recommend surgery or not. The other three patients could not be reached telephonically and no records could be found on satisfaction or whether they would recommend surgery.

Of the five patients who could be reached telephonically, one was self-employed and fully functional with no pain or limitation other than not regaining full extension. One patient was a bricklayer and had returned to work eight weeks following the surgery. Another patient was a car guard who had returned to work on last follow up but reported struggling with ADLs despite regaining a ROM of $40^{\circ}$ to $140^{\circ}$.

Three patients were unemployed and three were scholars. One unemployed housewife reported struggling with ADLs due to pain at times despite ROM of $20^{\circ}$ to $130^{\circ}$ (Table I). In addition, on her last follow-up she was found to have developed early post-traumatic elbow osteoarthritis (Table I). Of the three scholars, two reported no complaints of pain or ability to perform ADLs. The third scholar developed heterotopic ossification and a stiff elbow as a result. The remaining two patients could not be reached telephonically and no records could be found indicating occupation or ADLs. According to MEPI scores, two patients had excellent outcomes (scoring 100 and 95), three good (two scoring 85 and one scoring 80), and three fair (two scoring 60 and one with a score of 65 . One could not be scored as there was no recorded scoring on the file and telephonic contact was unsuccessful.

\section{Discussion}

This study aims to report on patient satisfaction following surgical treatment of chronic simple unreduced elbow dislocations. In addition we wanted to evaluate return to premorbid function and to gather information that may help in pre-operative counselling of patients in terms of the expected outcomes of surgery and rehabilitation.

The majority of acute elbow dislocations (80-90\%) are posterior or postero-lateral and result from a fall on outstretched hand with the forearm pronated. ${ }^{2,4,7,8}$ Other mechanisms of injury include high velocity motor vehicle accidents, assaults and sports-related injuries. Lateral, posterior medial, medial, anterior and divergent (characterised by displacement of the radius from the ulna) are much less common. ${ }^{4,8}$ Our results concur with the reported literature on the mechanism of injury and the direction of dislocation. Our cohort consisted of four posterior, four postero-lateral and one divergent dislocation, most of which were sustained following a simple fall.

Chronic elbow dislocations usually result from inadequate treatment of the acute injury. These injuries are common in developing countries and are usually treated initially by local bone setters and present late for orthopaedic opinion. ${ }^{1-3,6,7}$ Seven 
Table I: Summary of age distribution, clinical presentation, duration from injury to surgery, post-operative assessment, patient satisfaction and MEPI scores

\begin{tabular}{|c|c|c|c|c|c|c|c|c|c|c|c|}
\hline Patient & $\begin{array}{c}\text { Age } \\
\text { (years) }\end{array}$ & $\begin{array}{c}\text { Injury } \\
\text { mechanism }\end{array}$ & $\begin{array}{c}\text { Time to } \\
\text { presentation }\end{array}$ & $\begin{array}{l}\text { Deformity } \\
\text { flex/extension/ } \\
\text { radiographs }\end{array}$ & $\begin{array}{c}\text { ROM at } \\
\text { presentation }\end{array}$ & $\begin{array}{l}\text { Time to } \\
\text { surgery }\end{array}$ & $\begin{array}{c}\text { ROM } \\
\text { at final } \\
\text { follow-up }\end{array}$ & $\begin{array}{c}\text { Patient } \\
\text { satisfaction }\end{array}$ & $\begin{array}{l}\text { Return to } \\
\text { pre-injury } \\
\text { function }\end{array}$ & $\begin{array}{l}\text { MEPI } \\
\text { score }\end{array}$ & Complications \\
\hline 1 & 47 & $\begin{array}{l}\text { FOOSH in } \\
\text { June } \\
\text { Represented } \\
\text { in November }\end{array}$ & $\begin{array}{l}\text { Backslab and } \\
\text { discharged } \\
\text { immediately } \\
\text { post initial } \\
\text { injury }\end{array}$ & $\begin{array}{l}\text { Elbow extended } \\
\text { Posterior lateral } \\
\text { dislocation }\end{array}$ & $\begin{array}{l}\text { FFD } 30^{\circ} \\
\text { Full pronation } \\
\text { and } \\
\text { supination }\end{array}$ & $\begin{array}{c}5 \\
\text { months }\end{array}$ & $30-140^{\circ}$ & Satisfied & $\begin{array}{l}\text { Self-employed; } \\
\text { able to carry } \\
\text { all activities } \\
\text { at } 8 \text { months } \\
\text { post-op }\end{array}$ & 85 & $\begin{array}{l}\text { Pain on cold } \\
\text { weather only }\end{array}$ \\
\hline 2 & 40 & $\begin{array}{l}\text { FOOSH } \\
\text { September, } \\
\text { represented } \\
\text { in January } 2 \\
\text { weeks after } \\
\text { re-injury }\end{array}$ & $\begin{array}{l}\text { Immediately, } \\
\text { reduced and } \\
\text { treated on } \\
\text { collar and } \\
\text { cuff; then lost } \\
\text { to follow-up }\end{array}$ & $\begin{array}{l}\text { Extension } \\
\text { Posterior } \\
\text { dislocation }\end{array}$ & $0-80^{\circ}$ & $\begin{array}{c}7 \\
\text { months } \\
\text { from } \\
\text { initial } \\
\text { injury }\end{array}$ & $20-130^{\circ}$ & $\begin{array}{c}\text { Not } \\
\text { contactable }\end{array}$ & $\begin{array}{l}\text { Unemployed } \\
\text { housewife. } \\
\text { Struggles } \\
\text { with ADLs } \\
\text { (washing, } \\
\text { brushing teeth, } \\
\text { dressing) }\end{array}$ & 60 & $\begin{array}{l}\text { OA changes } \\
\text { noted on last } \\
\text { follow-up at } 26 \\
\text { months }\end{array}$ \\
\hline 3 & 27 & $\begin{array}{l}\text { FOOSH } \\
\text { while playing } \\
\text { soccer in } \\
\text { February }\end{array}$ & $\begin{array}{l}\text { Immediately } \\
\text { treated with } \\
\text { backslab for } \\
2 \text { months. } \\
\text { No history of } \\
\text { reduction of } \\
\text { post reduction } \\
\text { radiographs }\end{array}$ & $\begin{array}{l}\text { Flexion } \\
\begin{array}{l}\text { Posterior lateral } \\
\text { dislocation }\end{array}\end{array}$ & FFD $90^{\circ}$ & $\begin{array}{c}5 \\
\text { months }\end{array}$ & $40-140^{\circ}$ & $\begin{array}{l}\text { Contact } \\
\text { numbers } \\
\text { off on } \\
\text { multiple } \\
\text { attempts }\end{array}$ & $\begin{array}{l}\text { Car guard. } \\
\text { Struggles } \\
\text { with ADLs } \\
\text { (washing, } \\
\text { brushing teeth, } \\
\text { dressing) }\end{array}$ & 65 & $\begin{array}{l}\text { HTO which } \\
\text { never } \\
\text { progressed } \\
\text { nor required } \\
\text { surgery }\end{array}$ \\
\hline 4 & 6 & $\begin{array}{l}\text { FOOSH in } \\
\text { December }\end{array}$ & $\begin{array}{l}\text { Immediately } \\
\text { reduced, } \\
\text { put on collar } \\
\text { and cuff. No } \\
\text { follow-up } \\
\text { given }\end{array}$ & $\begin{array}{l}\text { Divergent } \\
\text { dislocation }\end{array}$ & $\begin{array}{l}\text { FFD } 90^{\circ} \\
\text { Supination } \\
90^{\circ} \text {, pronation } \\
40^{\circ}\end{array}$ & $\begin{array}{c}5 \\
\text { months }\end{array}$ & Stiff elbow & $\begin{array}{c}\text { Not } \\
\text { contactable }\end{array}$ & $\begin{array}{l}\text { Scholar; no } \\
\text { record of } \\
\text { function on } \\
\text { file and not } \\
\text { contactable }\end{array}$ & & $\begin{array}{l}\text { Required } \\
\text { repeat } \\
\text { surgery for } \\
\text { manipulation } \\
\text { under } \\
\text { anesthesia } \\
\text { and later } \\
\text { developed } \\
\text { HTO. Family } \\
\text { refused further } \\
\text { surgery and } \\
\text { reported the } \\
\text { child had } \\
\text { adapted to } \\
\text { using the limb }\end{array}$ \\
\hline 5 & 30 & $\begin{array}{l}\text { Fell off the } \\
\text { ladder in } \\
\text { February }\end{array}$ & $\begin{array}{l}\text { Presented } \\
16 \text { days post } \\
\text { injury }\end{array}$ & $\begin{array}{l}\text { Extension } \\
\text { Posterior } \\
\text { dislocation }\end{array}$ & FFD $30^{\circ}$ & $\begin{array}{c}6 \\
\text { months }\end{array}$ & $20-115^{\circ}$ & $\begin{array}{c}\text { Very } \\
\text { satisfied }\end{array}$ & $\begin{array}{l}\text { Bricklayer/ } \\
\text { builder. } \\
\text { Bread winner. } \\
\text { Returned to } \\
\text { full function } \\
\pm 10 \text { weeks } \\
\text { post-surgery }\end{array}$ & 95 & $\begin{array}{l}\text { None reported/ } \\
\text { documented }\end{array}$ \\
\hline 6 & 12 & $\begin{array}{l}\text { Fell while } \\
\text { playing in } \\
\text { June }\end{array}$ & $\begin{array}{l}\text { Immediately } \\
\text { treated with } \\
\text { backslab, no } \\
\text { information on } \\
\text { reduction or } \\
\text { post reduction } \\
\text { radiographs }\end{array}$ & $\begin{array}{l}\text { Extension } \\
\text { Posterior } \\
\text { dislocation }\end{array}$ & FFD $30^{\circ}$ & $\begin{array}{c}6 \\
\text { months }\end{array}$ & $40-90^{\circ}$ & Satisfied & $\begin{array}{l}\text { Scholar. Able } \\
\text { to carry out } \\
\text { all activities of } \\
\text { age, playing } \\
\text { well with } \\
\text { other children } \\
\text { and never } \\
\text { complains of } \\
\text { pain }\end{array}$ & 60 & $\begin{array}{l}\text { Superficial } \\
\text { wound sepsis } \\
\text { HTO on CT } \\
\text { scan which } \\
\text { was done due } \\
\text { to poor elbow } \\
\text { movement }\end{array}$ \\
\hline 7 & 24 & $\begin{array}{l}\text { Assaulted } \\
\text { and fell in } \\
\text { September }\end{array}$ & $\begin{array}{l}\text { Presented } \\
15 \text { days post } \\
\text { injury. Closed } \\
\text { reduction } \\
\text { attempted but } \\
\text { failed }\end{array}$ & $\begin{array}{l}\text { Extension } \\
\text { Posterior lateral } \\
\text { dislocation }\end{array}$ & Jog of ROM & 1 month & $40-120$ & Satisfied & $\begin{array}{l}\text { Unemployed. } \\
\text { No limitations }\end{array}$ & 80 & $\begin{array}{l}\text { None reported/ } \\
\text { documented }\end{array}$ \\
\hline 8 & 12 & $\begin{array}{l}\text { FOOSH in } \\
\text { June }\end{array}$ & $\begin{array}{l}\text { Immediately } \\
\text { treated with } \\
\text { backslab. No } \\
\text { information on } \\
\text { reduction and } \\
\text { post reduction } \\
\text { radiographs }\end{array}$ & $\begin{array}{l}\text { Extension } \\
\text { Posterior } \\
\text { dislocation }\end{array}$ & $\begin{array}{l}\text { FFD } 30^{\circ}, \\
\text { jog of } \\
\text { pronation and } \\
\text { supination }\end{array}$ & $\begin{array}{c}5 \\
\text { months }\end{array}$ & $30-130^{\circ}$ & Satisfied & $\begin{array}{l}\text { Scholar. Full } \\
\text { function and } \\
\text { plays without } \\
\text { limitations }\end{array}$ & 100 & $\begin{array}{l}\text { None reported/ } \\
\text { documented }\end{array}$ \\
\hline 9 & 28 & $\begin{array}{l}\text { Assault/ } \\
\text { FOOSH in } \\
\text { January. } \\
\text { Re-injured } \\
\text { in June } \\
\text { ( } 3 \text { weeks } \\
\text { prior to 2nd } \\
\text { presentation }\end{array}$ & $\begin{array}{l}\text { Immediately } \\
\text { reduced, } \\
\text { backslab } \\
\text { No closed } \\
\text { reduction } \\
\text { attempted on } \\
2 \text { nd injury }\end{array}$ & $\begin{array}{l}\text { Extension } \\
\text { Posterior lateral } \\
\text { dislocation }\end{array}$ & FFD $35^{\circ}$ & $\begin{array}{l}1 \text { month } \\
\text { after } \\
\text { re-injury }\end{array}$ & $\begin{array}{l}20^{\circ} \text {-full } \\
\text { flexion }\end{array}$ & Satisfied & $\begin{array}{l}\text { Unemployed. } \\
\text { Able to carry } \\
\text { out all daily } \\
\text { activities with } \\
\text { minimal pain }\end{array}$ & 85 & $\begin{array}{l}\text { Joint } \\
\text { crepitations at } \\
\text { final follow-up } \\
\text { Pain in cold } \\
\text { weather }\end{array}$ \\
\hline
\end{tabular}


$(77.7 \%)$ of our patients were treated at emergency units, some of which had no record of reduction nor confirmation of reduction on radiographs. In addition, some patients received inadequate treatment as they were placed in a collar and cuff followed by discharge without an adequate rehabilitation plan. Two patients did not seek any treatment as they did not initially recognise the severity of the injury.

Treatment of old unreduced posterior dislocations of the elbow is one of the challenges that face orthopaedic surgeons in developing countries. ${ }^{1,9,10}$ Clinical findings include an extended or flexed elbow with wasting of the triceps and a palpable bony deformity (Figures 4 and 5). Common findings at surgery include shortening of the triceps, firm adhesions and contracture of the capsule and collateral ligaments, dense osteo-fibrous tissue in the olecranon fossa (Figures 1 and 6), coronoid fossa and trochlea notch and the presence of heterotopic ossification. ${ }^{10}$ These usually prevent closed reduction in chronic elbow dislocations and hence surgical treatment is advocated by most surgeons. Our intra-operative findings were consistent with that described by other authors.

Successful treatment is a challenge and depends on obtaining and maintaining concentric reduction of the ulno-humeral and radio-capitellar joints as well as a functional arc of motion in order to complete ADLs. ${ }^{8,9}$ We achieved concentric reduction on all patients. ROM in terms of flexion and extension varied between patients (Table I). Eight patients had full pronation and supination post-surgery while one patient developed a stiff elbow.

Bansal et al. reported on three patients treated with open reduction, $\mathrm{V}-\mathrm{Y}$ plasty and intra-articular cortisone injection. ${ }^{1}$ Two of their patients had chronically unreduced simple elbow dislocation while one had chronically complex unreduced elbow dislocation. They reported two excellent results on simple dislocations and one good result on complex dislocation according to the MEPI. Although chronic complex elbow dislocation was included in their report, their results are comparable to available literature as well as our results. None of our patients required triceps lengthening. A similar observation was made by Islam et al. who treated 13 patients, three with associated fractures and ten without. ${ }^{2}$ Twelve of their patients did not require $\mathrm{V}-\mathrm{Y}$ plasty of the triceps. They also report satisfactory outcomes in 11 patients with six excellent, five good, one fair and one poor outcome. We are of the opinion that triceps lengthening should be individualised to patients in whom reduction cannot not be obtained without lengthening.

The MEPI is a useful score system for these injuries are it assesses pain intensity, motion of the joint, stability and function. A score of more than 90 is considered excellent, $75-89$ good, $60-74$ fair and less than 60 is considered poor. Our results are consistent with results obtained by Mehta et al. in their series of ten patients. They reported five excellent, three good and two poor outcomes in a series of ten cases. ${ }^{6}$

Chowdhury et al. managed 15 cases of simple unreduced elbow dislocations. ${ }^{3}$ They reported four cases with good results, seven fair and four poor according to the Krishnamoorthy score. They attributed less satisfactory results to lack of post-operative exercise facilities., ${ }^{3,6} \mathrm{We}$ agree that it is essential to have a facility that can facilitate planned, goal-directed therapy. We faced similar challenges as most of our patients were referred from remote areas and therefore could not fully participate in the rehabilitation programme.

Jupiter et al. treated five patients with open reduction and the use of hinged external fixator. They reported two excellent and three good results with an average MEPI of $89 .{ }^{11}$ We treated one patient with an external fixator for joint distraction. Our patient developed heterotpic ossification and subsequently joint stiffness. He was, however, able to carry out some activies using shoulder joint positioning.

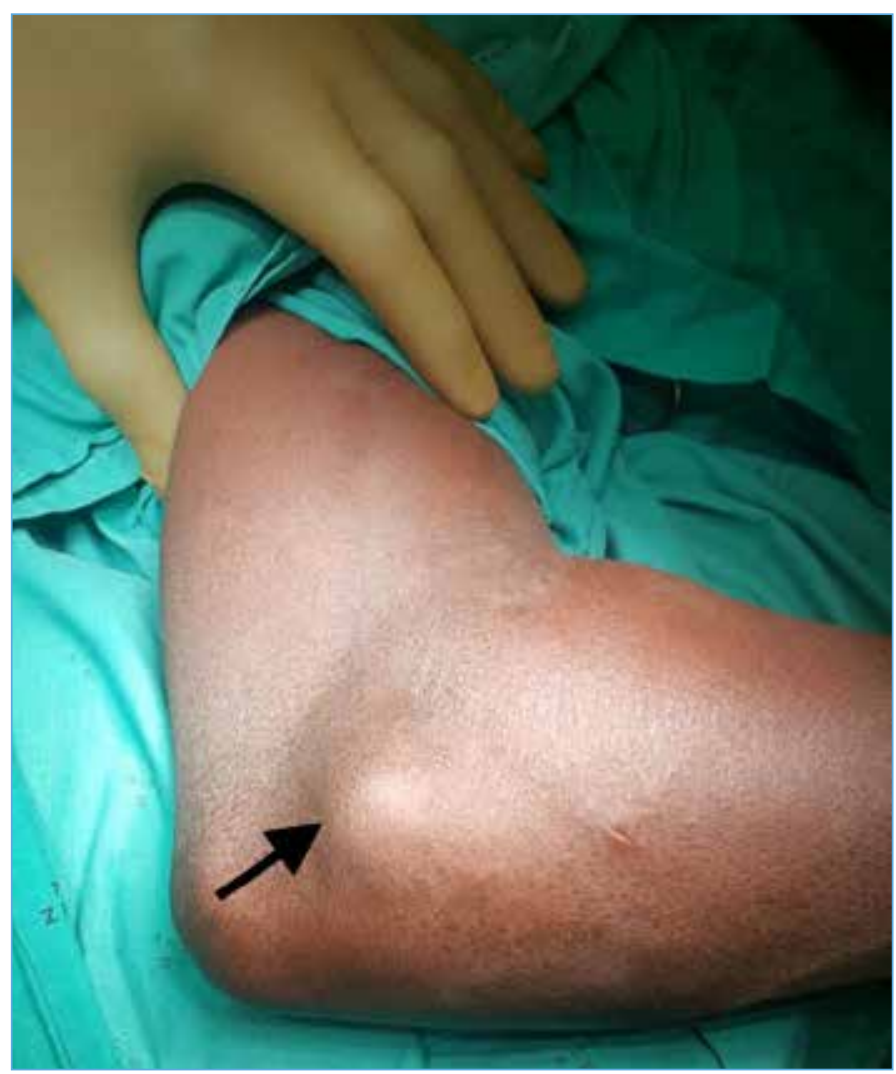

Figure 4. Elbow flexion is limited and a lateral bony mass is shown signifying posterior lateral dislocation.

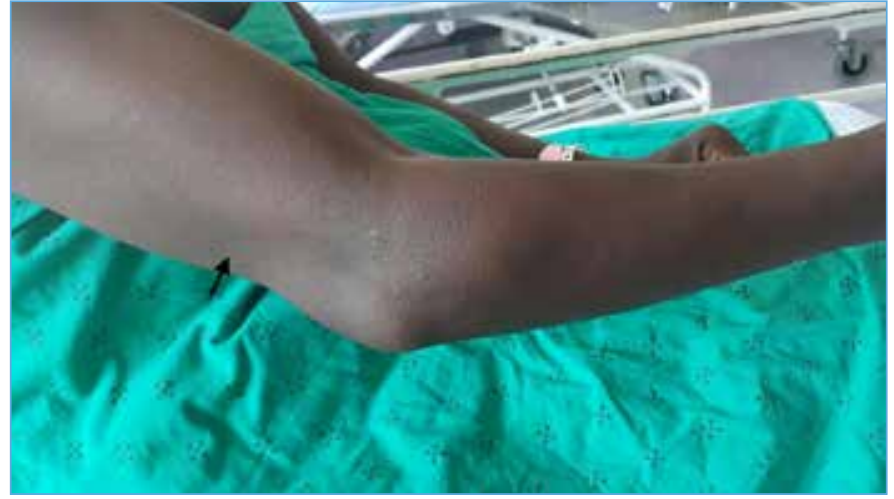

Figure 5. Showing a semi-flexed position of the elbow, wasting of the triceps and prominent olecranon

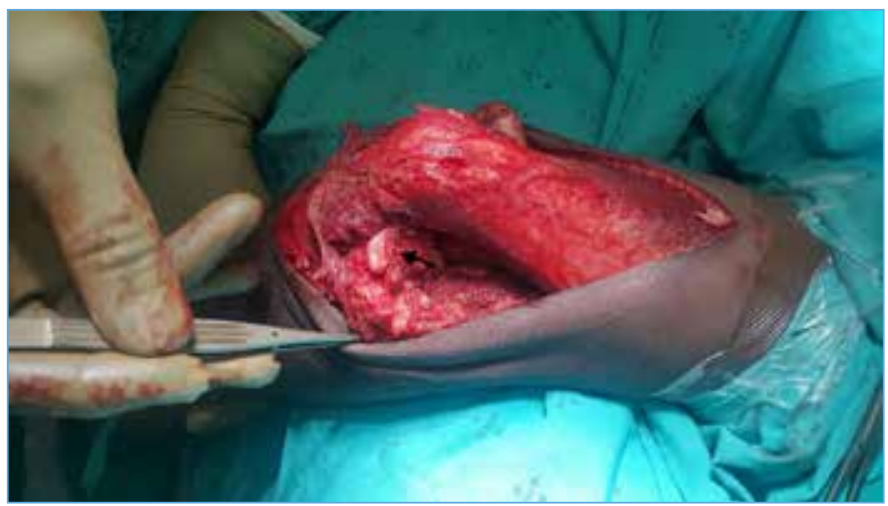

Figure 6. Triceps is shortened and there is presence of fibrous tissue.

A more recent study by Anderson et al. included 22 patients treated with medial and lateral approaches to the elbow without triceps lengthening. ${ }^{12}$ The authors demonstrated $97 \%$ of good or excellent results with low complication rate. ${ }^{12}$ Their study also supports preservation of extensor mechanism and allowed for early 
ROM as there was no risk of rupturing recently repaired soft tissues. We do not have experience with early ROM at our institution.

There were several limitations to this study. Due to the low incidence of these injuries, only a small number of patients were treated. Our series does however have similar patient numbers as other published studies in international literature. Hospital records at our facility are only kept for five years and not stored on microfilm or electronic records. This unavailability of some patient records impacted our study results. We did not perform formal assessment of DASH or patient-rated elbow evaluation (PREE) scores for comparison with other studies. MEPI scores were obtained from the files as well as after contacting the patients telephonically. Most patients were referred from peripheral hospitals far from our institution and were often from poor backgrounds; this resulted in poor follow-up and poor adherence to rehabilitation protocols.

\section{Conclusion}

Patients with chronic simple elbow dislocation experience improved function following surgical treatment. Extensive counselling about surgical treatment and prolonged rehabilitation should be discussed with the patient prior to surgery. Emergency practitioners need to be able to diagnose, reduce, check elbow stability post reduction and properly splint patients who present with acute elbow dislocations. Furthermore a planned follow-up and rehabilitation should be standardised for each institution and be given to patients after treatment of acute dislocations. We recommend social worker referral and financial support for all patients who require it in order to facilitate adherence to the prolonged rehabilitation programme. Where possible, patients should be seen by occupational therapists pre- and post-operatively. This helps build rapport between the patient and the therapist and ensures adherence to a post-operative rehabilitation programme.

\section{Ethics statement}

Ethical approval was obtained from the institutional ethics committee before commencement of the study.

\section{References}

1. Bansal P, Lal H, Khare R, Mittal D. Treatment of neglected elbow dislocation with combination of Speed $\mathrm{V}-\mathrm{Y}$ muscleplasty and intra-articular injection of corticosteroid. Kathmandu University Medical Journal 2010;8(29):91-94.

2. Islam S, Jahangir J, Manzur RM, Chowdury AA, Tripura N, das A. Management of neglected elbow dislocation in a setting with low clinical resources. Orthop Surg 2012;4:177-81.

3. Chowdhury AM, Hossain MA, Rahman MN. Treatment of old unreduced posterior dislocation of the elbow. Dinajpur Med $\mathrm{Col} J$ 2009;2(2):44-47.

4. Donohue KW, Mehlhoff TL. Chronic elbow dislocation: Evaluation and management. J Am Acad Orthop Surg 2016;24:413-23.

5. Rubino LJ, Herbenick MA, Finnan RP, Anloague PAL. Chronic elbow dislocation treated with open reduction and lateral ulnar collateral ligament reconstruction. Am J Orthop 2009;38(6):E98-E100.

6. Mehta S, Sud SA, Tiwari A, Kapoor SK. Open reduction for late-presenting posterior dislocation of the elbow. J Orthop Surg 2007;15(1):15-21.

7. Lyons RP, Armstrong A. Chronically unreduced elbow dislocations. Hand Clinic 2008;24(1);91-103.

8. Neuhaus V, Alqueza $A$. Open reduction and temporary internal fixation of sub-acute elbow dislocation. $J$ of Hand Surg 2012;37A: 1011-14.
9. Rolando I. Treatment of chronically unreduced complex dislocations of the elbow. Strat Trauma Limb Recon 2009;4(2):49-55.

10. KS Naidoo. Unreduced posterior dislocation of the elbow. $J$ Bone Joint Surg Br 1982;64:603-606.

11. Jupiter JB, Ring D. Treatment of unreduced elbow dislocation with hinged external fixation. J Bone Joint Surg 2002;84-A(9):1630-35.

12. Anderson DR. Surgical treatment of chronic elbow dislocation allowing for early range of motion: operative technique and clinical results. J Orth Trauma 2018;32(4):196-203. 